\title{
Loss in the Time of COVID-19: a New Narrative
}

\author{
Christina Amerault ${ }^{1}$
}

Received: 23 January 2021 / Accepted: 21 April 2021/ Published online: 18 May 2021

(C) Academic Psychiatry 2021

"Is it your job to keep me alive or to give me a better life?" he asked during one of our early sessions. I was taken aback. This wasn't the last time he would ask me a question that would challenge my identity as a doctor, a foundation already unsteady as a new third-year resident navigating the world of outpatient psychiatry.

We began meeting for therapy twice weekly last July and slowly he shared his story with me. Born in America, he felt immense pressure to succeed given the sacrifices his immigrant parents had made for him. He was supposed to have gone to college; however, his mental health had interfered. Sitting with him, I was struck by how tangible his pain was; it often felt like it engulfed me in the same way I imagine it deluged him. Apart from discussing his narrative, he often spoke of more existential domains, trying to make sense of the ugliness of humanity, largely blind to any of the beauty. He described feeling "victim to the chemical journey in his brain."

I wish I could say the highs outnumbered the lows, but the reality was that at times, his suffering seemed relentless. Nevertheless, I stuck by. I learned that the more obstinate he was, the worse he was doing. I also got to know he had a soft spot for cat videos, wrote poetry, enjoyed video games, and was funny in the same dark, satirical way that I have a tendency to be. We occupied an easy space and I grew quite fond of him. Over time, he started to show signs of hope by applying for some jobs and even discussing the prospect of college.

In the winter, his despair took a turn for the worst. COVID19 was just a whisper in the news, but his fear of contracting the virus was paralyzing. He also started worrying incessantly about me-bringing up "vicarious trauma," and questioning what it would look like if our work together "went bad." Once, in a desperate effort to both comfort him and disavow myself, I said, "I have a whole team of people who are supporting me. I will be fine no matter what." This statement still troubles

Christina Amerault ceamerault@challiance.org

1 Cambridge Health Alliance, Harvard Medical School, Cambridge, MA, USA me-could he have thought I was freeing him to take his own life? Of course, this question presupposes that we, as psychiatrists, hold the power to keep our patients alive.

He killed himself in April of that year. Our recent sessions had been held on video chat given my department's mandate to halt in-person visits due to COVID-19. I remember his disappointment, lamenting that he felt "more alone than ever." He hadn't gotten a job and virtual college did not feel feasible. Despite this, at our last session, he promised to be alive for our next meeting. My risk assessment was thorough. I asked every question I have been trained to ask. Towards the end of our last conversation, he described a beautiful scenic setting in the outskirts of town. I was happy he had found some joy. This was the place he killed himself.

I will never forget getting the call from his mother that he was missing, staying up all night waiting for an update, hearing the news the next morning, and spending the next days oscillating between numbness, anger, and deep sadness. So many thoughts spiraled through my mind-I'm a bad doctor. I should have known. How could he do this? My patients shouldn't trust me. Are my colleagues judging me? Are my supervisors disappointed in me? I'm hurt. I'm angry. I miss him so much. Months later, these thoughts sometimes still creep up, but I push forward with a deepened sense of modesty and a heightened awareness of the fragility of life.

I tell my patients that the patient-therapist relationship can feel strange and one-sided, yet at the end of the day, it is just two people developing a relationship that contains a unique type of intimacy. The loss of that relationship by suicide brings forth not only grief but also self-doubt and insecurity for the fresh trainee. In contrast to oncologists who are taught to expect death as a possible outcome, suicide is sometimes wrongly framed as a "preventable death" that we should be able to stop. Of course this isn't always true. As one of my wise supervisors noted, "we fantasize that the relationship between us and our patients will keep them alive, but the heartbreaking reality is that sometimes it is not enough."

While for this patient, the pandemic meant a loss of hope and thus a descent back down into the crater he had only begun to ascend, for many other people social distancing for 
their medical health has caused a sharp decline in their mental health. The intensity of individual loneliness and fear of the pandemic must be seen as its own public health crisis and we, as providers, must rise to the challenge. For me, going through this loss in the time of COVID-19 only deepened the sense of grief and isolation. While my family, peers, and supervisors have been incredibly supportive, I long for the physical cohabitation of space in order to not hold this pain alone.

I go back to his question, "Is it your job to keep me alive or to give me a life?" Over a year later, I believe the answer was "neither." We cannot keep our patients alive, nor can we grant them a better life. We can only bear witness to their suffering and try to walk with them towards peace. While I still feel broken by this experience, what I've valued most from my supervisors is them being able to do just that - sit with my pain and not try to "fix it," recognizing that time will heal, but never completely. I hope I was able to do that for him, if only temporarily.

\section{Declarations}

Disclosures The author states that there is no conflict of interest.

Publisher's Note Springer Nature remains neutral with regard to jurisdictional claims in published maps and institutional affiliations. 